\title{
Local Government Challenges' to Implement Public Private Partnership Projects in Indonesia
}

\author{
Erwin, SONDANG S. \\ erwinsondangsiagian@yahoo.com \\ Asep, SUMARYANA \\ asep.sumaryana@unpad.ac.id \\ Ida, WIDIANINGSIH \\ ida.widianingsih@unpad.ac.id \\ Heru, NURASA \\ hnurasa@yahoo.com \\ Public Administration Department, Faculty of Social and Political Sciences \\ Universitas Padjadjaran, Indonesia
}

\begin{abstract}
This paper aims is to analyze several challenges' those faced by local governments in Indonesia, including its provinces, districts and cities, in implementing the Public Private Partnership (PPP) scheme. The analysis is focused on 3 challenges, as follows: 1) budget; 2) regulations (Act Number 23 of 2014 concerning Regional Government, Government Regulation Number 27 of 2014 concerning Government Asset Management and Presidential Regulation Number 38 of 2015 concerning Public and Private Partnership for Provision of Infrastructure), and 3) the party that involve on PPP projects. Therefore, some of the developed recommendations are expected to be solution for the local government in addressing these challenges.
\end{abstract}

Keywords: Public Private Partnership, Implementing, Challenges, Local Government, Indonesia

JEL Classification: $\mathrm{H} 5, \mathrm{H7}$.

\section{Acknowledgement}

Thank you to LPDP (Lembaga Pengelola Dana Pendidikan) for providing scholarship to pursue my study and for supporting this research. Scholarship from LPDP has helped many Indonesian students to continue their study. 


\section{Introduction}

As of 2014, Indonesia has 34 provinces, 415 districts and 93 Cities $^{1}$. Each province, district and city performs an administrative duty. In carrying out such governmental functions, each local government must have the regional budget which is determined within every financial year.

Regional budget itself is a unit consisting of: regional income, regional expenditure; and regional financing. Regional budget is very important to carry out local government authority.

There are $32^{2}$ divisions of government affairs between the central government and provincial and district / city government, consisting of the: 1) education, 2) health, 3) public works and spatial, 4) housing and residential areas, 5) peace/tranquillity and public order and protection of society, 6) social, 7) labor, 8) women empowerment and children protection, 9) food, 10) land, 11) environment, 12) population administration and civil registration, 13) community and village empowerment, 14) population control and family planning, 15) transportation, 16) communication and informatics, 17) cooperatives, small businesses, and medium enterprises, 18) investment, 19) youth and sports, 20) statistical, 21) coding ( intelligence, 22) cultural, 23) library, 24) archiving, 25) maritime affairs and fisheries, 26) tourism, 27) agricultural, 28) forestry, 29) energy and mineral resources, 30) trading, 31) industrial, and 32) transmigration.

In order the local government to exercise the authority, public infrastructure is needed. Provision of public infrastructure can be conducted through regional budget, state owned enterprise / regional owned enterprise budget, private budget, and / or through cooperation / partnership between local government and business entity under PPP scheme. The availability of good public infrastructure, of course, is needed in providing excellent service to the public. Then, this paper analyses local government challenges' in implementing the PPP scheme.

\section{Methodology}

This study uses a qualitative research method. Data analysis is descriptive, that is descripting data and fact of research. Data collection techniques are conducted through document studies, interviews, and / or in-depth discussions. Data analysis is conducted since the data collection by giving analysis to the data.

1 http://otda.kemendagri.go.id/CMS/Images/SubMenu/total_daerah_otonom.pdf last accessed on September 7, 2017 09.24 WIB.

2 Law Number 23 of 2014 on Regional Government. 
Data analysis is open, which means that analysis is adaptive of changing and improving based on new data. Furthermore, the questions in this study are formulated as follows:

a) What are budget challenges in providing infrastructure?

b) What are regulations challenges in providing infrastructure through local government cooperation, utilization of local government assets, or public private partnership?

c) What are the Business Entity challenges in the PPP project?

\section{Public Private Partnership}

PPP aspects can be identified as follows: a long-term contract ${ }^{34}$ between the Government (in Indonesia, this matter referred to as the Government Contracting Agency (GCA)) and private sector or business entity; Risk sharing ${ }^{5}$; Government support ${ }^{6}$, and Return of investment ${ }^{7}$. These aspects are well-known on Indonesian PPP regulation.

Erwin $^{8}$ (2017) stated as many as 5 sectors that have been implemented through PPP scheme in Indonesia. Furthermore, the Ministry of Finance of Republic of Indonesia ${ }^{9}$ stated that 9 projects have reached the signing of PPP agreement. Thus, it can be concluded that only few sectors or projects have been implemented through PPP scheme in Indonesia.

There are 3 regulations which are directly related to the PPP scheme in Indonesia, namely: Law Number 23 Year 2014 on Regional Government, Government Regulation Number 27 Year 2014 on Government Asset Management, and Presidential Regulation Number 38 of 2015 on Public and Private Partnership for Provision of Infrastructure. Analysis in this paper is focused on the local government challenges in implementing the PPP scheme based on these three regulations. In addition to these regulations, of course there are many other regulations according to the PPP sector, but will not be discussed in this paper.

\footnotetext{
${ }^{3}$ World Bank. 2012. Public-Private Partnership Reference Guide Version 1.0.

${ }^{4}$ Asian Development Bank. Public-Private Partnership Handbook.

${ }^{5}$ United Nation Economic and Social Commission for Asian and The Pacific. 2011. Guide Book on Promoting Good Governance in Public-Private Partnership.

${ }^{6}$ Presidential Regulation Number 38 of 2015 Public and Private Partnership for Provision of Infrastructure

${ }^{7}$ Presidential Regulation Number 38 of 2015 Public and Private Partnership for Provision of Infrastructure

${ }^{8}$ Erwin Sondang Siagian 2017. Public-private partnerships in Indonesia: a comprehensive legal framework of significance to action and analysis. Asia Pacific Journal of Public Administration, p.72-78.

${ }^{9}$ https://www.kemenkeu.go.id/media/3381/ppp.pdf
} 
As previously mentioned, the return of investment is one of the main aspects on PPP. In Indonesia, there are $3^{10}$ forms that can be used for business investment returns, namely: user charge, availability payment, and other forms in accordance with the provisions of legislation.

With the form of user charge, the public must pay for every using of public infrastructure that provided by business entities, such as payment for the use of toll roads, the use of medical devices, the use of water, and so forth. User charge is very commonly used in the PPP scheme.

If the local governments provide regional budget to pay the services or infrastructres that provided by business or private entity, it is said as the implementation of the form of the availability payment. The availability payment is a new model in Indonesia. Thus, the analysis in this paper is focused on the budget challenges that will be faced by local governments when implementing the availability payment that funded by regional budget.

Furthermore, the most important aspect on PPP is the partnership between local government and private/business entity. To implement the partnership, of course it is required a reliable local government apparatus. Thus, this paper will identify the local government human resources aspect. In addition to analysing from the local government side, this paper also examines the challenges faced by private/business entity when participating in PPP project.

\section{Findings}

\subsection{Budget Challenges}

As has been described earlier, that local government must establish the Regional Budget annually. The Regional Budget that has been established consist of regional revenues, regional expenditures, and regional financing. Then, regional expenditures consist of a) personnel expenditure, b) goods and services expenditure, c) capital expenditures, d) interest, e) subsidies, f) grants, g) social assistance, h) revenue-sharing and financial assistance, and i) unexpected expenditure.

Regional financing consists of a financing revenues and financing expenditures. The financing expenditures include: a) establishment of a reserve fund, b) local government capital participation/inclusion c) payment of debt principal; and d) provision of lending/credit. This shows that the composition of the Regional budget has been defined very detailed.

\footnotetext{
10 Presidential Regulation Number 38 of 2015 on Public and Private Partnership for Provision of Infrastructure.
} 
Ministry of State Apparatus of Republic of Indonesia ${ }^{11}$ stated that there were many local governments budgeted employees expenditures more than $50 \%$, with the following details: 1) 58 regions with the ratio of employees expenditure in the regional budget of more than $60 \%$, 2) 300 regions with employees expenditure of less than 50\%, and 3) 177 regions with employees expenditure of around $50 \%$ to $60 \%$.

Furthermore, there must also be a percentage of the budget that must be provided as mandated by legislation. Article 31 para 4 of the 1945 Constitution stated that the State prioritizes budget for education to at least $20 \%$ of the state budget and local government budget to meet the needs of national education.

Law Number 36 of 2009 on Health states "the amount of health budget of the provincial, district / city governments should be allocated at least $10 \%$ of the regional revenue and expenditure budget beyond the salaries". Law No. 6 of 2014 on the village states that the Village Fund Allocation shall be at least $10 \%$ of the balancing funds received by District / Municipal (city) in Revenue and Expenditure Budget after deduction of the Special Allocation Fund.

Based on the above description, the setting for the percentage of expenditure budget that must be provided consists of Education, Health and / or Allocation of Village Fund can be seen in Table 1 below:

Table 1. Estimated Composition of Regional budget

\begin{tabular}{|l|l|l|l|}
\hline Expenditure & Provincial Budget & $\begin{array}{l}\text { Regional Budget that } \\
\text { does not have Villages }\end{array}$ & $\begin{array}{l}\text { Regional Budget that } \\
\text { has Villages }\end{array}$ \\
\hline $\begin{array}{l}\text { Employees } \\
\text { expenditure }\end{array}$ & less than 50\% up to more than $60 \%$ of the Regional budget \\
\hline Health expenditure & $10 \%$ of the Regional budget (excluding/beyond the salaries) \\
\hline $\begin{array}{l}\text { Education } \\
\text { Expenditure }\end{array}$ & $20 \%$ of the Regional budget \\
\hline $\begin{array}{l}\text { Allocation of Village } \\
\text { Fund expenditure }\end{array}$ & - & - & $\begin{array}{l}10 \% \text { of the balancing } \\
\text { funds after deducting } \\
\text { by Special Allocation } \\
\text { Fund. }\end{array}$ \\
\hline
\end{tabular}

Source: Authors

The estimated composition of the Regional budget as described in Table 1 above can be different every year among local governments. The limited budget presents major challenge for local governments in implementing 32 local government affairs, especially in providing public infrastructure.

\footnotetext{
${ }^{11}$ Employees Expenditures in 58 Regions/Areas is More Than 60 Percents, http://www.menpan.go.id/beritaterkini/5796-belanja-pegawai-di-58-daerah-lebih-dari-60-persen accessed on February 17th, 2017 at 16:30 WIB.
} 
The Ministry of National Development Planning/National Development Planning Agency (2015) stated that Indonesia requires funding to the tune of IDR. 4,769.2 Trillion to meet the funding requirements in order to provide infrastructure from 2015 to 2019.

The need for such a level of funding is expected to be fulfilled by $41 \%$ of the government budget, amounting to $22 \%$ of the State/ Regional Owned Enterprises, and a further by $37 \%$ of the private sector or business entity. National Development Planning Agency data showed that there were sizeable gaps between the government's funding ability and the need for infrastructure funding. In order to address this gap PPP scheme is required.

\subsection{Regulation Challenges}

\subsubsection{Cooperation Based on Law No. 23 of 2014}

The Law Number 23 of 2014 provides the basis for implementing the functions and tasks of local government. In order to improve people's welfare, the local government can conduct cooperations that based on efficiency and effectiveness considerations of public services as well as mutually beneficial. This cooperation must also be mutually benefial.

Such cooperation can be conducted by the local government to: a). another local government; b). third party; and / or c). a foreign agency in accordance with the provisions of the legislation.

The challenge is on the word of "mutual benefit". However, if one analyse it more in depth, the word "mutual benefit" can have multiple interpretations:

It could mean that every local government in implementing the cooperation should receive benefit. However, this raises the question of what benefit means. For private entities it most probably refers to financial gain but it is more difficult to determine the meaning of benefit for a public body.

- It raises the question of what the exact definition/formulation of such profit-sharing arrangement is?

Furthermore, if the provision/delivery of public infrastructure is fully utilized by private resources, should the government still receive any benefit/profit? The definition of such multiple interpretations could potentially cause legal problems in the future.

Then, the term of "third parties" relates to the the private/business entity, community organizations, as well as other non-governmental organizations. 
The cooperation between local government bodies and third parties shall include: a). cooperation in the provision of public services; b). cooperation in asset management to increase the added value that provides income for the region; c). investment cooperation; and d). other cooperation that is not in contrary to the provisions of the legislation.

One of the most important stages in a cooperation project is the preparation of a feasibility study document. However, questions over who should conduct the studies remain.

The challenges in the preparation of the feasibility study are more obvious when looking at the models or forms of cooperation, as follows: a). cooperation in the provision of public services; b). cooperation in asset management in order to increase the added value that provides income for the region; $c$ ). investment cooperation; and d). other cooperation that is permissible by the provisions of the legislation. In a cooperative project, the feasibility study will significantly affect the success or failure of a PPP project.

Act Number 23 of 2014 also dictates that further provisions regarding the cooperation are regulated by government regulation. Until now, the government regulation in question has not been formulated. As it has not been articulated by the government, the regulation cannot be analyzed by the parties involved.

\subsubsection{Cooperation Based on Government Regulation 27 of 2014.}

The cooperation is based on the mandate of Government Regulation 27 of 2014 concerning Government Asset Management. This regulation is the guideline for central government utilized its asset and local governments utilized their asset. The analysis in this paper is focused on the use of local government asset.

The utilization of local government asset is the utilization of asset which is not used for the implementation of tasks and functions of local government department and / or optimization of local government asset by not changing status of its ownership. It means that the asset is still owned by regional government.

The criteria that must be met in order to be able to implement the use of such local government asset: a). property manager/administrator with the approval of the governor / head of district / mayor, for the regional owned property which is in the possession of property manager/administrator or b).u ser of goods/property with the approval of property manager/administrator, for 
local government asset partly in the form of land and / or building that are still being used by the user of goods/property concerned, and other than land and / or buildings.

Analysed shown that there are five forms of the utilization of local government asset that can be used, namely: a). rent; b). lease; c). utilization cooperation; d). build operate transfer or build transfer operate; or e). cooperation for provision of infrastructure. The five forms of utilization of the local government asset have their own characteristics.

The rent is local government asset utilization by the other party within a certain period. The lease usage is the use delivery of goods/property between the central government and local government or among the local governments within a certain period without receiving rewards and after the expiration of the period the assets to be returned to the property manager/administrator.

Furthermore, utilization cooperation is the use of local government asset by other parties within a specified period in order to increase non-tax revenues / regional income (revenue) and other financing sources.

While build operate transfer is the utilization of regional owned property in the form of land by another party by means of establishing a building and / or infrastructure along with its facilities, and then being utilized by the other party within a certain period that has been agreed upon, the land and infrastructure along with its facilities will subsequently be returned after the expiration of the period. Build transfer operate is the utilization of local government asset in the form of land by another party by means of establishing building and infrastructure along with its facilities, and once the construction is completed it shall be handed over to be utilized by the other party within a certain period as agreed. The cooperation for provision of infrastructure is a collaboration between the government and a business enterprises for the provision of infrastructure in accordance with the provisions of legislation.

The provisions of legislation referred to by the utilization of cooperation for the provision of infrastructure is the legislation regulation related to PPP, especially in the following in eight economic sectors. Those eight sectors are: transportation, road, water resource, drinking water, waste water, telecommunication, electricity; and / or oil and / or gas.

The parties involved in implementing the use of local government asset consist of the regional head (governor, head of district or mayor), government agencies/bodies (central and other regions), and / or cooperation partners. The cooperation period is stipulated to be a maximum for 50 years.

The following challenges that will be faced in the cooperation of local government asset are: 
1. The utilization of local government asset shall only be done to local government asset which is not used for the implementation of duties and functions of the regional apparatus unit and / or optimizing the local government asset by not changing the ownership status. In addition to these two things, then the use of local government asset cannot be done for any reason. Thus, the utilization of local government asset can hardly be done for the unsolicited PPP project.

2. In addition to the challenges that are not easy to get the approval of the Head of Region, the next challenge is not clear differences in the utilization of local government asset through the cooperation of utilization; build operate transfer or build transfer operate; and cooperation of infrastructure provision. This uncertainty has the potential to become a legal problem in the future.

\subsubsection{Partnership Based on Presidential Regulation Number 38 of 2015}

Presidential Regulation Number 38 of 2015 is a substitute of Presidential Decree Number 67 of 2005 and its amendment. Presidential Decree Number 67 of 2005 and the amendment itself is a substitute of Presidential Decree Number 7 of 1998. Although the arrangement of the PPP has been regulated since 1998, until now only a few sectors have been implemented under PPP scheme. Thus, local governments (including elements of the human resources apparatus of local governments) have little experience in implementing PPP projects.

Under this new Perpres there are 19 sectors that can be cooperated through PPP scheme, namely: 1) transportation; 2) road; 3 ) water resources and irrigation; 4) drinking water; 5) centralized waste water management system; 6) localized waste water management system; 7) waste management system; 8) telecommunication and informatics; 9) electricity; 10 ) oil and gas and renewable energy; 11) energy conservation; 12) urban facilities; 13) educational facilities; 14) sports facilities, as well as arts; 15) regional infrastructure; 16) tourism; 17) health; 18) correctional institution; and 19) public housing. The above nineteenth types of infrastructure can be grouped into 2, namely, economic infrastructures and social infrastructures. 


\subsection{The Party challenges}

\section{The parties involved}

Presidential Regulation Number 38 of 2015 also has identified the parties that involved in a PPP project. Those parties are the government and business entities.

The parties that involved from the government side are: Government Contracting Agency (GCA), PPP Node, PPP Team, and Procurement Committee. To implement a PPP project, the GCAs are the governor, head of district, and mayor. Head of region must issue a letter that determination himself or herself as the GCA of a PPP project.

Then, a PPP Node has a very important role in helping head of local government within all phases of the PPP project, starting from the preparation, the planning, the transaction, and the implementation. It can be attached to the local government agency that has been already available. PPP node can be as a new local government agency that is established only to run the PPP node functions. The functions are: to conduct policy formulation, synchronization, coordination, supervision, and / or evaluation of all PPP activities. To handle all of these functions, a PPP Node can be assisted by a PPP team in preparatory phase and the PPP transactions phase; and by procurement committee in carrying out procurement activity. A PPP node must be determined soon after a decision of a project has been taken to be implemented through PPP scheme.

Furthermore from the government side is a PPP team. A PPP team is set by the GCA. A PPP team should be formed for each PPP project. A PPP team is soon established after the PPP node has been formed. A PPP team has function to assist the GCA to do the initial and final review of pre-feasibility study at the preparation phase; and to achieve the compliance of financing, apart from the procurement of implementing business entities at transactional phase; to prepare a periodic project report; and to coordinate with PPP node. A PPP team also has responsibilities, namely: coordinating with the procurement committee during the procurement process; preparing the terms of reference (ToR) for the Preparation Agency or Procurement Body; and assisting the GCA in monitoring the implementation of the procurement.

Then, next step in implementing a PPP project is the GCA forms the procurement committee. The procurement committee has function to procure the implementing business entity at the transaction phase. To be assigned as a procurement committee these criteria must be fulfilled: they are an odd numbered and at least 5 people and can be added (if necessary); understand the procurement procedures, the PPP procedures, the PPP project's scope of work, 
the legal issues of a PPP project, the technical aspects of the PPP project, and the financial and business aspects of the PPP project. The procurement committee also prohibited from having an affiliation with other procurement committee members, the GCA, the PPP node, and participants. Each of the procurement committee members must sign an Integrity Pact.

As having been mentioned earlier, a number of PPP projects that have been implemented under PPP scheme are very limited. Of course, it causes the ability, competence, and experience of the head of region, PPP Node, PPP Team, and PPP Procurement Committee to implement the PPP project are also very limited too.

\section{Private or business entity}

To implement a PPP projects, the local government is seek a private or business entity that will implement a PPP projects. In Indonesia, a private or business can be a state-owned enterprise (SOE), a regional-owned enterprise (ROE), private enterprises in the form of a limited liability company, foreign business entity, and/or cooperative.

In a PPP procurement process, the private or business entity can stand alone or in a consortium. The same as the government side, private and business entities are also prohibited from having a conflict of interest with the government side as well as to other private and business entities. Having been declared as the winner, the winning business entities must establish which iimplementing business entities will sign the PPP Agreement.

The issue is for a small-scale project. For small-scale projects, they should not be required to establish an implementing business entity. The bid winning bbusiness entities should instantly become executive/implementing business entity. Until now, there are a very limited number of local governments that are implementing their projects through a PPP scheme.

\section{Conclusions}

a. In accordance with Law Number 23 of 2014, local governments have 32 authorities for governmental affairs. Based on the cooperation arrangement/provision in this Act, the provision of facilities and infrastructure including the implementation of service to all of 32 such authorities can be cooperated. However there is no further arrangements relating to the implementation of such cooperation. Government Regulation Number 27 of 2014 mandates that local government asset can be exploited through Rent, Lease and Use, Utilization Cooperation, Build Operate Transfer or Build Transfer 
Operate; or Cooperation for the Provision of Infrastructure. However the setting/regulation to choose the cooperation partner cannot be a guidee to the regional government in implementing the scheme utilization of Regional Owned Property. Presidential Regulation Number 38 of 2015 has mandated four of the implementing regulations. There are at least 2 matters that could potentially be an obstacle in implementing the PPP scheme, namely 1) an obligation to form/establish implementing business entities (special purpose company), or 2) the transactional phase has not been arranged in the Presidential Regulation.

b. There is a gap in funding ability between the central government and local governments compared with the financing needs to provide the necessary public infrastructure. Such a sizeable/large gap can be overcome by involving business entities in the provision of public infrastructure.

c. Based on the analysis of the cooperation arrangements as contained in Law Number 23 of 2014, Government Regulation Number 27 of 2014 and Presidential Regulation Number 38 of 2015, it is necessary to have legislation regulation harmonization. Such harmonization is very important in order to have legal certainty in the implementation of local government cooperation. In order to prevent discrepancies in interpretation of the use of legislation in implementing the cooperation or partnership scheme, there should be only one setting/regulation related to cooperation or partnership for local governments.

d. In the arrangement of this single regulation, the project implementation stage is required, as the implementation stage of this project is the most important step so that the business entity can provide the required infrastructure and at the same time the legal reference for the local government in overseeing the standard of service provided.

e. With the limited National/Regional Budget and the limited number of local governments that implement PPP projects, it is better to establish/determine a PPP pilot project. The success of this pilot PPP project will be the benchmark of local governments in implementing PPP projects.

f. In order to assist local leaders/heads in PPP project, the head of the region should form a PPP Node which is involved in all PPP stages. Then the head of the region should established a PPP Team that will assist local leaders/heads in the planning and preparation per phase of PPP project, and define the Procurement Committee which implements procurement agencies and / or business entities of the implementing PPP project. 


\section{References}

[1] Employees Expenditures in 58 Regions/Areas is More Than 60 Percents, http://www.menpan.go.id/berita-terkini/5796-belanja-pegawai-di-58-daerah-lebih-dari-60persen accessed on February 17th, 2017 at 16:30 WIB

[2] http://otda.kemendagri.go.id/CMS/Images/SubMenu/total_daerah_otonom.pdf last accessed on September 7, 2017 09.24 WIB

[3] Agency for Public Private Partnership Republic Of Croatia. 2009. A Step-By-Step Guide to Public Private Partnerships.

[4] Asian Development Bank. No year. Public-Private Partnership Handbook.

[5] Asian Development Bank. 2010. Improving Health and Education Service Delivery in India through Public-Private Partnerships.

[6] Asian Development Bank. 2013. Guidebook on Public-Private Partnership in Hospital Management.

[7] Cavinoto, Joseph L, and Kauffman Ralph G. National Association of Purchasing Management. Sixth Edition. 2000. The Purchasing Handbook; A Guide for the Purchasing and Supply Professional.

[8] Government Regulation Number 23 of 2005 and its revision (Government Regulation Number 74 of 2012) regarding Budget Management of Public Service Agency.

[9] Government Regulation Number 27 of 2014 regarding Government Asset Management.

[10] http://www.unescap.org/ttdw/ppp/ppp_primer/121_steps_in_ppp_project_development_ and_implementation.html. Accessed on September 11, 2017 08.50 PM.

[11] International Finance Corporation. 2010. IFC Support to Health Public-Private Partnerships.

[12] Katz, Dieter. 2006. New Zealand Treasury: Financing Infrastructure Projects: Public Private Partnerships (PPPS).

[13] King, Donald B and Ritterskamp, Jr, James J. Prentice Hall. Third Edition (1998). Purchasng Manager's Desk Book of Purchasing Law.

[14] Law Number 36 of 2009 regarding Health.

[15] Law Number 44 of 2009 regarding Hospital.

[16] Law Number 6 of 2014 regarding the Village.

[17] Law Number 23 of 2014 regarding Regional Government.

[18] OECD. 2014. Private Financing And Government Support To Promote Long-Term Investments In Infrastructure.

[19] Presidential Decree No. 7 of 1998 regarding Cooperation between the Government and Private Business Entities in Infrastructure Development and or Management.

[20] Presidential Regulation No. 67 of 2005 regarding Cooperation between the Government and Private Business Entities in Infrastructure Development and or Management.

[21] Presidential Regulation No. 13 of 2010 regarding Cooperation between the Government and Private Business Entities in Infrastructure Development and or Management.

[22] Presidential Regulation No. 56 of 2011 regarding Cooperation between the Government and Private Business Entities in Infrastructure Development and or Management. 
[23] Presidential Regulation No. 66 of 2013 regarding Cooperation between the Government and Private Business Entities in Infrastructure Development and or Management.

[24] Presidential Regulation No. 38 of 2015 regarding Public and Private Partnership for Provision of Infrastructure.

[25] Siagian, Erwin Sondang. 2017. Public-private partnerships in Indonesia: a comprehensive legal framework of significance to action and analysis. Asia Pacific Journal of Public Administration, p.72-78.

[26] The 1945 Constitution.

[27] The National Public Procurement Agency Head Regulation Number 19 Year 2015 regarding the Procedures for the Implementation of the Business Entity Procurement in the Public Private Partnership for the Provision of Infrastructure.

[28] United Nation Economic and Social Commission for Asian and The Pacific. 2011. Guide Book on Promoting Good Governance in Public-Private Partnership.

[29] World Bank. 2011. How to Engage with the Private Sector in Public-Private Partnership in Emerging Markets.

[30] World Bank. 2012. Public-Private Partnership Reference Guide Version 1.0.

[31] Yescombe, E.R. 2010. Public-Private Partnership: Principles of Policy and Finance. 